\title{
Effects of Different Water Harvesting on Soil Water, Growth and Yield of the Proso Millet (Panicum miliaceum L.) in a Semiarid Region of Northwest China
}

\author{
Yang $\mathrm{Qu}^{1,2}$, Wang $\mathrm{Su}^{1}$, Panpan Zhang ${ }^{1}$, Cui $\mathrm{Li}^{1}$, Jinfeng Gao ${ }^{1}$, Xiaoli Gao ${ }^{1}$, Pengke Wang ${ }^{1}$, Shuhuai Jiang ${ }^{1}$ \& \\ Baili Feng ${ }^{1}$ \\ ${ }^{1}$ State Key Laboratory of Crop Stress Biology on Drought Regions, Northwest A \& F University, Yangling, \\ Shaanxi, China \\ ${ }^{2}$ Institute of Agricultural Science, Baoji, Shaanxi, China \\ Correspondence: Baili Feng, State Key Laboratory of Crop Stress Biology on Drought Regions, Northwest A \& \\ F University, Yangling, Shaanxi, 3,Taicheng road, China. Tel: 86-29-8708-2889. E-mail: 7012766@163.com
}

Received: May 11, 2012 Accepted: May 30, 2012 Online Published: July 26, 2012

doi:10.5539/jas.v4n9p106

URL: http://dx.doi.org/10.5539/jas.v4n9p106

\begin{abstract}
Field experiments were conducted to study the effects of different water harvesting on soil water, growth, yield and water use efficiency of the proso millet in a semiarid region of northwest China in 2010-2011. The experiment included five treatments: a flat plot with no mulching (NM) and four alternation ridge and furrow only the ridge mulched with white plastic film (PRFRH) systems. The cultivation system could increase soil water content of the furrow and maintained soil water content in ridges, there was better effect of water saving in P40, then P60 compared with NM. This system also promoted proso millet growth and yield development, P60 was higher agronomic characters compared with other treatments $(\mathrm{P}<0.05)$. Proso millet yield and water use efficiency significantly increased by $73.87 \%-147.00 \%$ and $75.58 \%-185.54 \%$ compared with $\mathrm{NM}(\mathrm{P}<0.05)$, respectively. Evapotranspiration (ET) decreased by $3.93 \mathrm{~mm}-101.40 \mathrm{~mm}$ than NM. The best width of ridge: furrow was between $60 \mathrm{~cm}$ and $64 \mathrm{~cm}$.
\end{abstract}

Keywords: proso millet, water harvesting, PRFRH system, semiarid region

\section{Introduction}

All the time, precipitation becomes an important limiting factor for crop production in semiarid regions of northwest China (He et al., 2007), this region has low rainfall, soil evaporation is high, and water use efficiency is low. Therefore, to maximize utilization of precipitation through rainfall collection and conservation techniques is necessary for agricultural practices.

In order to reduce evaporation and ensure the crop production of local people, conservation tillage has been used as a means of conserving soil and water resources to increase crop yield. However, the effectiveness of conservation tillage depends on soil type, climate, and land slope (Tolk et al., 1999; Lampurlanes et al., 2002; Zhang et al., 2009). Conservation tillage increased crop yield or got similar yields to conventional tillage according to $89 \%$ of studies, and decreased crop yields according to about $11 \%$ of studies (Xie et al., 2008). Therefore, conservation tillage should remain some uncertainties.

In arid and semiarid regions other field management practices, such as water harvesting, have been extensively applied for crop planting. The newest practices include alternating ridge and furrow, the ridge obtains water to furrow, and furrow is irrigated and planted (Moharrery \& Shayannejad, 2009) for increasing crop yield. Lal et al. (1984) found that the use of a 'W'-shaped in situ rainfall harvesting system was effective for improving crop production in Brazil. Fisher (1995) reported that semi-permanent plastic mulching system left the plastic mulch in situ for a period of years, reused plastic mulching under the traditional mulching system, reduced plastic mulching cost, combined improved water management, decreased risk of soil erosion, and higher yields, which was the similar as alternating ridge and furrow with mulched ridges in plastic film. Gupta (1995) thought that the bare ridge and furrow method of rainwater harvesting significantly improved the growth of Azadirachta indica, Tecomella undulata and Prosopis cineraria trees in the Indian desert. Li et al. (2001) reported that the plastic mulched ridge and furrow rainfall harvesting (PRFRH) system improved water efficiency and increased corn 
yield over the bare ridge and furrow harvesting (RFRH) system under semiarid conditions in northwest China. Wang et al. (2009) reported that the PRFRH system could be an optimal practice to improve runoff efficiency, rainwater harvesting and crop yield. The field micro-environment greatly distinguished the PRFRH system from the RFRH system.

Proso millet (Panicum miliaceum L.) is the main crop in the semiarid Loess region of northwest China. However, proso millet productivity in this area is often limited by drought stress (Pan et al., 2012). To increase the efficiency is the key to improve proso millet yield. Therefore, we designed four different water harvesting modes based on alternation ridge and furrow only the ridge mulched with white plastic film (PRFRH), the objectives of this study were to determine: (a) the effects of dry matter, leaf area and plant height in different treatments, (b) soil water storage and its distribution in soil profile would differ with various width of ridge: furrow, (c) proso millet yield and water use efficiency would also be affected.

\section{Materials and Methods}

\subsection{Study Site Description}

Field experiment to evaluate the possible benefits of plastic mulch options were conducted at Canghemao Experimental Station, Northwest A \& F university, Fugu, Shaanxi province $\left(39.09^{\circ} \mathrm{N}, 111.01^{\circ}\right.$ E and altitude $1000 \mathrm{~m}$ ) in two seasons during 2010 and 2011 . The climate is semiarid with annual mean precipitation of 366.2 $\mathrm{mm}$, and rainfall is mainly between July and September. The mean annual temperature is $9.1^{\circ} \mathrm{C}$ with a maximum of $38.9^{\circ} \mathrm{C}$ and the minimum of $-24^{\circ} \mathrm{C}$. The average annual pan evaporation is $1092.2 \mathrm{~mm}$. The average annual sunshine duration is $2890 \mathrm{~h}$ with over 177 frost-free days. Soil type is loessial. Analysis of the top soil $(0-20 \mathrm{~cm})$ obtained the following results: organic $\mathrm{C}, 19.32 \mathrm{~g} \mathrm{~kg}^{-1}$; nitrate $\mathrm{N}, 1.2 \mathrm{~g} \mathrm{~kg}^{-1}$; available $\mathrm{P}, 6.4 \mathrm{mg} \mathrm{kg}^{-1}$; available $\mathrm{K}$, $89 \mathrm{mg} \mathrm{kg}^{-1}$; ammonium N $\left(\mathrm{NH}_{4}^{+}+\mathrm{NO}_{3}^{-}\right) 44.3 \mathrm{mg} \mathrm{g}^{-1}$ and soil bulk density is $1.50 \mathrm{~g} \mathrm{~cm}^{-3}$.

\subsection{Experimental Design}

In this study, five treatments were designed as follows: a flat plot with no mulching(NM), the width of ridges: furrow were $40 \mathrm{~cm}: 40 \mathrm{~cm}(\mathrm{P} 40), 60 \mathrm{~cm}: 60 \mathrm{~cm}(\mathrm{P} 60), 80 \mathrm{~cm}: 80 \mathrm{~cm}(\mathrm{P} 80)$ and $100 \mathrm{~cm}: 100 \mathrm{~cm}(\mathrm{P} 100)$, respectively. Only the ridges $(10 \mathrm{~cm}$ high) mulched with white plastic film. A diagram showing the ridge and furrow system (P40) is presented in Figure 1. Furrows of P40, P60, P80, P100 were planted 2, 3, 4, 5 rows. P40, P60, P80, and P100 had four alternation ridges and furrows, their plot area were $3.2 \times 5 \mathrm{~m}^{2}, 4.8 \times 5 \mathrm{~m}^{2}, 6.4 \times 5 \mathrm{~m}^{2}$ and $8.0 \times 5 \mathrm{~m}^{2}$, respectively. The plot of NM was planted 8 rows, area was $3.2 \times 5 \mathrm{~m}^{2}$.All treatments were three replications that were arranged in a randomized block design. The entire experimental area was ploughed after all fertilizers ( 34.5 $\mathrm{kg} \mathrm{N} \mathrm{ha}^{-1}, 9.0 \mathrm{~kg} \mathrm{P}_{2} \mathrm{O}_{5} \mathrm{ha}^{-1}$ ) were incorporated into the soil surface. P40-P100 had the ridge covered with 0.008 $\mathrm{mm}$ thick plastic film. The density was $5.0 \times 10^{5}$ plants.ha $^{-1}$. Proso millet cultivar "Yumi 2" was planted on 11 June 2010, and reaped on 25 September 2010. The next year, it was planted on 12 June, and reaped on 23 September.

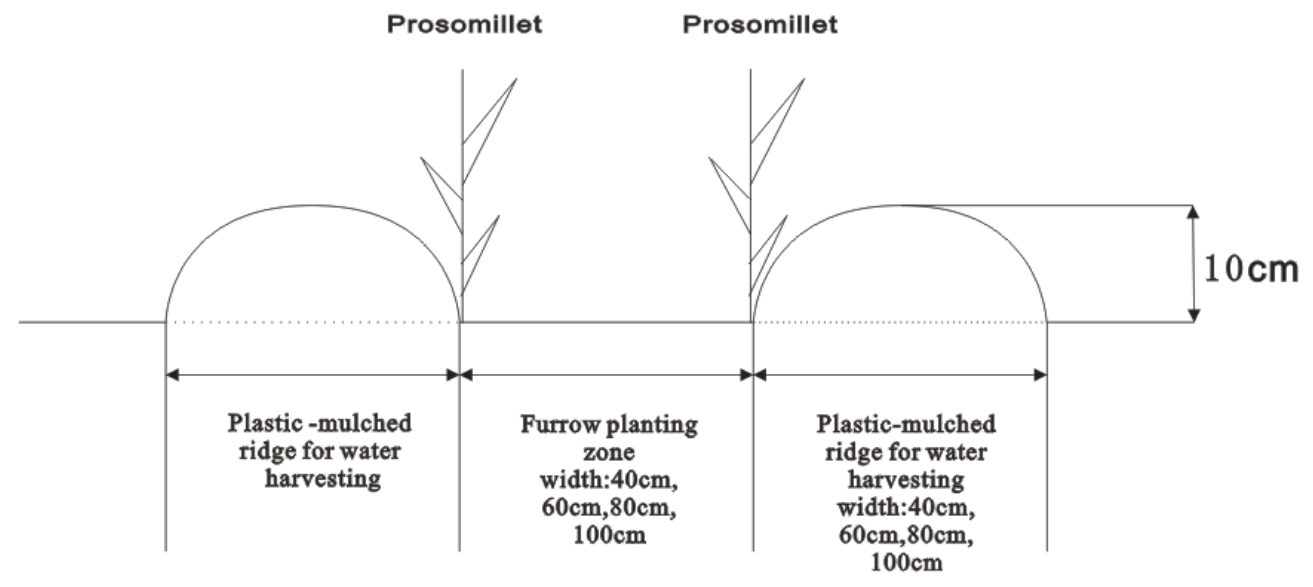

Figure 1. A diagram showing ridge and furrow water harvesting system with plastic mulches

\subsection{Sampling and Measurements}

Plants were sampled approximately monthly for leaf area and biomass determinations. Initially, five plants and 
subsequently three plants were randomly sampled from each plot, located at least $1 \mathrm{~m}$ from plot edges and $0.5 \mathrm{~m}$ from previous sampling sites. All the leaves of the sampled plants in each treatment plot were collected and weighted. About 20 representative leaves were cut with a special hollow auger with an internal radius of $6 \mathrm{~mm}$. The weight and area of the leaf wafers were then determined. The leaf area of all the sampled plants was estimated by the ratio between the weight of the 20 leaf wafers and that of all the sampled leaves (Hou et al., 2010). Then, total above ground biomass was determined gravimetrically after oven drying, at $105^{\circ} \mathrm{C}$ for $30 \mathrm{~min}$ initially and then at $65^{\circ} \mathrm{C}$ for $48 \mathrm{~h}$.

The water content in the soil profile was determined at depth intervals of $20 \mathrm{~cm}$, down to $100 \mathrm{~cm}$. Measurements were made approximately every two weeks during the proso millet growing season and have continued since the start of the experiment. Soil water storage (SWS) in the profile was considered to be the total storage $(0-100 \mathrm{~cm})$. Evapotranspiration (ET) (Zhang et al., 2011) was determined using the formula:

$$
\mathrm{ET}=\mathrm{P}+\mathrm{SW}_{\mathrm{p}}-\mathrm{SW}_{\mathrm{h}}
$$

$\mathrm{P}$ is the precipitation $(\mathrm{mm})$ during the crop growth season and $\mathrm{SW}_{\mathrm{p}}$ is the amount of soil water storage at planting $(\mathrm{mm})$ based on the mean value from furrow and ridge and $\mathrm{SW}_{\mathrm{h}}$ is the amount of soil moisture stored at harvesting $(\mathrm{mm})$, without considering deep percolation and runoff. Water use efficiency (WUE) was calculated as grain yield (GY) in $\mathrm{kg} \mathrm{ha}^{-1}$ divided by total water use in $\mathrm{m}$ (evaluated as ET in the present study):

$$
\text { WUE }=\text { GY/ET }
$$

Treatment means were compared using Duncan' method $(\mathrm{P}<0.05)$ by SAS v6 software.

\section{Results}

\subsection{Weather Conditions}

Rainfall during the proso millet growing season was to $274.0 \mathrm{~mm}$ in 2010, $165.7 \mathrm{~mm}$ in 2011, accounting for $102 \%, 62 \%$ of annual precipitation, respectively. Growing season in 2010 was more rainfall than that of 2011, rainfall distribution varied from June to September, more rainfall appeared in June, August and September 2010 than the same months of 2011, less rainfall in July 2010 than that of 2011 (Figure 2).

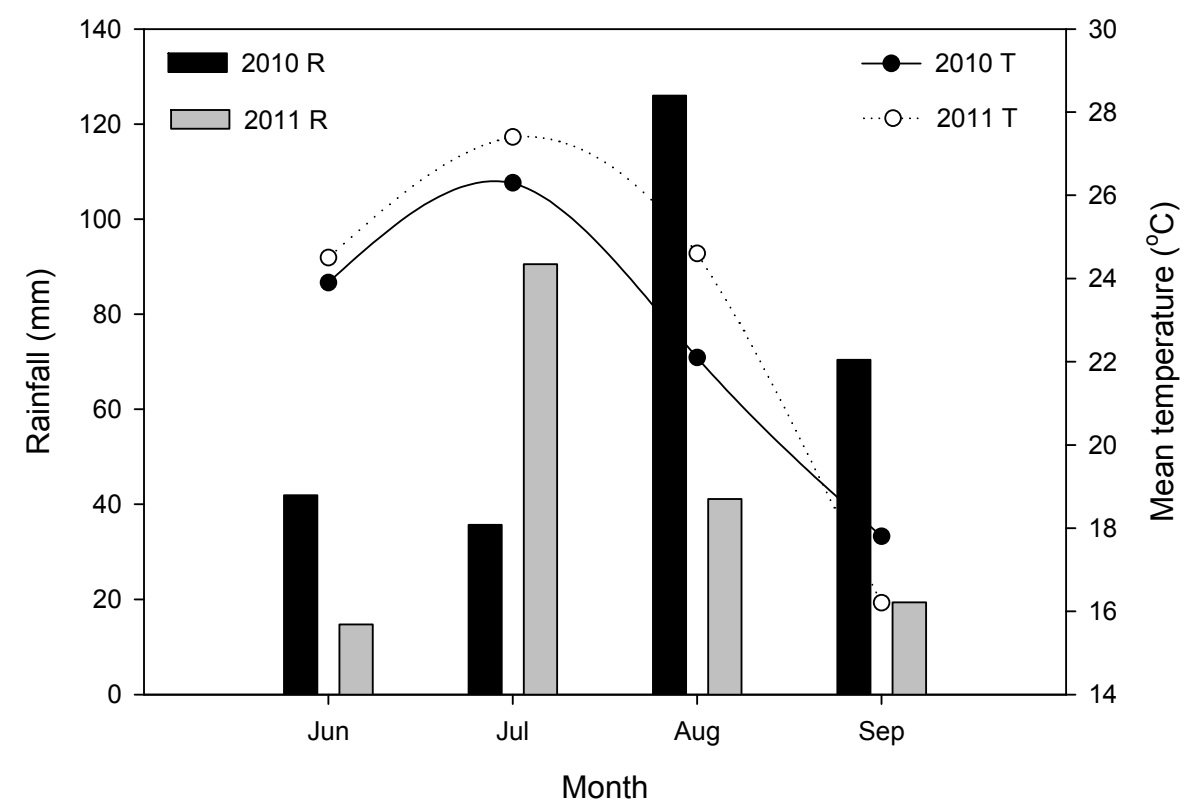

Figure 2. Distribution of monthly rainfall and mean temperature during proso millet growing seasons in 2010-2011 
Air temperature also varied greatly between the two growing seasons (Figure 2). There were significantly higher temperature in June, July, August 2011 than those in 2010, and lower temperature in September 2011 than that in 2010. The differences in rainfall and air temperature during growing time might influence proso millet development and lead to yield change.

\subsection{Aboveground Dry Matter, Leaf Area and Plant Height}

Aboveground dry matter and leaf area per plant were measured when proso millet was at jointing in July and filling in August (Table 1). In 2010, all treatments had more dry matter, leaf area and plant height than those of NM, P60 was significantly $(\mathrm{P}<0.05)$ higher than others in July and August. In 2011, every treatment had more dry matter, leaf area and plant height than those of NM, P60 was significantly $(\mathrm{P}<0.05)$ higher than others. Dry matter, leaf area and plant height of all treatments in 2010 were higher than those of all treatments in 2011.

Table 1. Aboveground dry matter, leaf area and plant height per proso millet plants for rainfall harvesting treatments at two sampling dates during the 2010 growing season

\begin{tabular}{cclllll}
\hline \multirow{2}{*}{ Sampling date } & & \multicolumn{5}{c}{ Treatment } \\
\cline { 3 - 7 } & & \multicolumn{1}{c}{ P100 } & P80 & \multicolumn{1}{c}{ P60 } & \multicolumn{1}{c}{ P40 } & NM \\
\hline \multirow{2}{*}{ July, 2010 } & Dry matter $(\mathrm{g})$ & $2.82 \mathrm{~b}$ & $3.00 \mathrm{ab}$ & $3.67 \mathrm{a}$ & $3.15 \mathrm{a}$ & $2.01 \mathrm{c}$ \\
& Leaf area $\left(\mathrm{m}^{2}\right)$ & $0.0405 \mathrm{bc}$ & $0.0478 \mathrm{~b}$ & $0.0686 \mathrm{a}$ & $0.0514 \mathrm{~b}$ & $0.0288 \mathrm{c}$ \\
& Plant height $(\mathrm{cm})$ & $41.13 \mathrm{c}$ & $43.38 \mathrm{bc}$ & $47.19 \mathrm{a}$ & $44.30 \mathrm{~b}$ & $40.18 \mathrm{c}$ \\
August,2010 & Dry matter $(\mathrm{g})$ & $38.65 \mathrm{c}$ & $45.23 \mathrm{bc}$ & $52.05 \mathrm{a}$ & $48.15 \mathrm{~b}$ & $28.75 \mathrm{~d}$ \\
& Leaf area $\left(\mathrm{m}^{2}\right)$ & $0.0757 \mathrm{~cd}$ & $0.1023 \mathrm{bc}$ & $0.1548 \mathrm{a}$ & $0.1136 \mathrm{~b}$ & $0.0599 \mathrm{~d}$ \\
& Plant height $(\mathrm{cm})$ & $134.36 \mathrm{c}$ & $144.92 \mathrm{bc}$ & $149.70 \mathrm{a}$ & $146.79 \mathrm{ab}$ & $133.03 \mathrm{~d}$ \\
\multirow{3}{*}{ July, 2011 } & Dry matter(g) & $3.34 \mathrm{c}$ & $3.67 \mathrm{~b}$ & $4.48 \mathrm{a}$ & $4.08 \mathrm{~b}$ & $2.99 \mathrm{c}$ \\
& Leaf area $\left(\mathrm{m}^{2}\right)$ & $0.0081 \mathrm{~b}$ & $0.0090 \mathrm{a}$ & $0.0098 \mathrm{a}$ & $0.0094 \mathrm{a}$ & $0.0060 \mathrm{c}$ \\
& Plant height $(\mathrm{cm})$ & $23.34 \mathrm{~d}$ & $30.30 \mathrm{c}$ & $33.93 \mathrm{a}$ & $31.70 \mathrm{~b}$ & $22.23 \mathrm{e}$ \\
& Dry matter $(\mathrm{g})$ & $10.96 \mathrm{c}$ & $12.29 \mathrm{~b}$ & $17.39 \mathrm{a}$ & $14.62 \mathrm{~b}$ & $8.94 \mathrm{~d}$ \\
& Leaf area $\left(\mathrm{m}^{2}\right)$ & $0.0095 \mathrm{~b}$ & $0.0096 \mathrm{~b}$ & $0.0117 \mathrm{a}$ & $0.0114 \mathrm{a}$ & $0.0070 \mathrm{c}$ \\
& Plant height $(\mathrm{cm})$ & $107.36 \mathrm{~d}$ & $109.87 \mathrm{c}$ & $114.00 \mathrm{a}$ & $112.87 \mathrm{~b}$ & $103.83 \mathrm{~d}$ \\
\hline
\end{tabular}

Note: Same letter indicates no significant difference at $P<0.05$ level. The same as below

\subsection{Soil Water}

The soil water storage (SWS) dynamics $(0-100 \mathrm{~cm})$ showed different patterns in the two experimental seasons (Figure 3). In 2010, SWS was depleted within the proso millet growing seasons, with low values in July 25 and August 20. All treatments were higher SWS than NM, and P40 was higher SWS than others during this seasons. In 2011, SWS generally decreased up to proso millet mature period. In all treatments, P40 had higher SWS than others. However, there was no significantly difference in growing period.
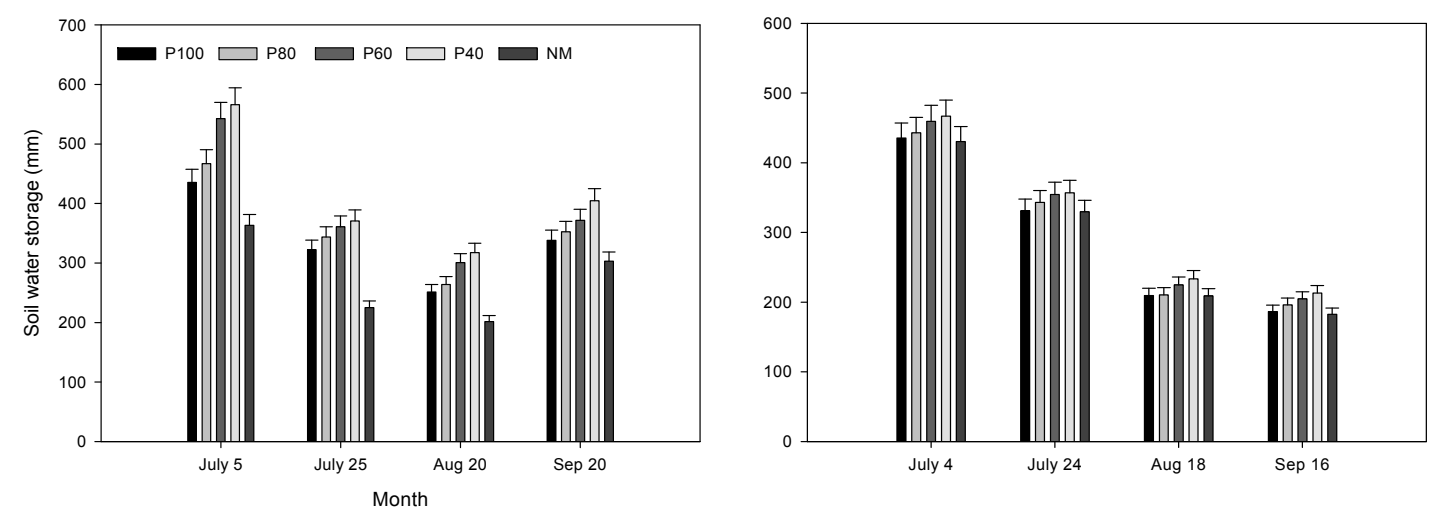

Figure 3. Change in soil water storage $(0-100 \mathrm{~cm})$ under NM, P100, P80, P60 and P40 treatments in two proso millet growing seasons: 2010 (left panel), 2011( right panel) 
The soil water content in the profile at harvest under all treatments reflected significantly depletion of soil water in deep soil layers, relative to those prior to planting in the first experimental season (Figure 4). The P40 and P60 treatments significantly increased the soil water content in the upper $60 \mathrm{~cm}$ soil layer compared with others. There was the same trend at the next growing seasons. In $80 \mathrm{~cm}-100 \mathrm{~cm}$ soil layer, P60 was lower soil water content than other treatments, then P40 in 2010, and there was the same trend in 2011. Between planting and harvesting, soil water content had significantly difference in both years, soil water was depleted apparently.
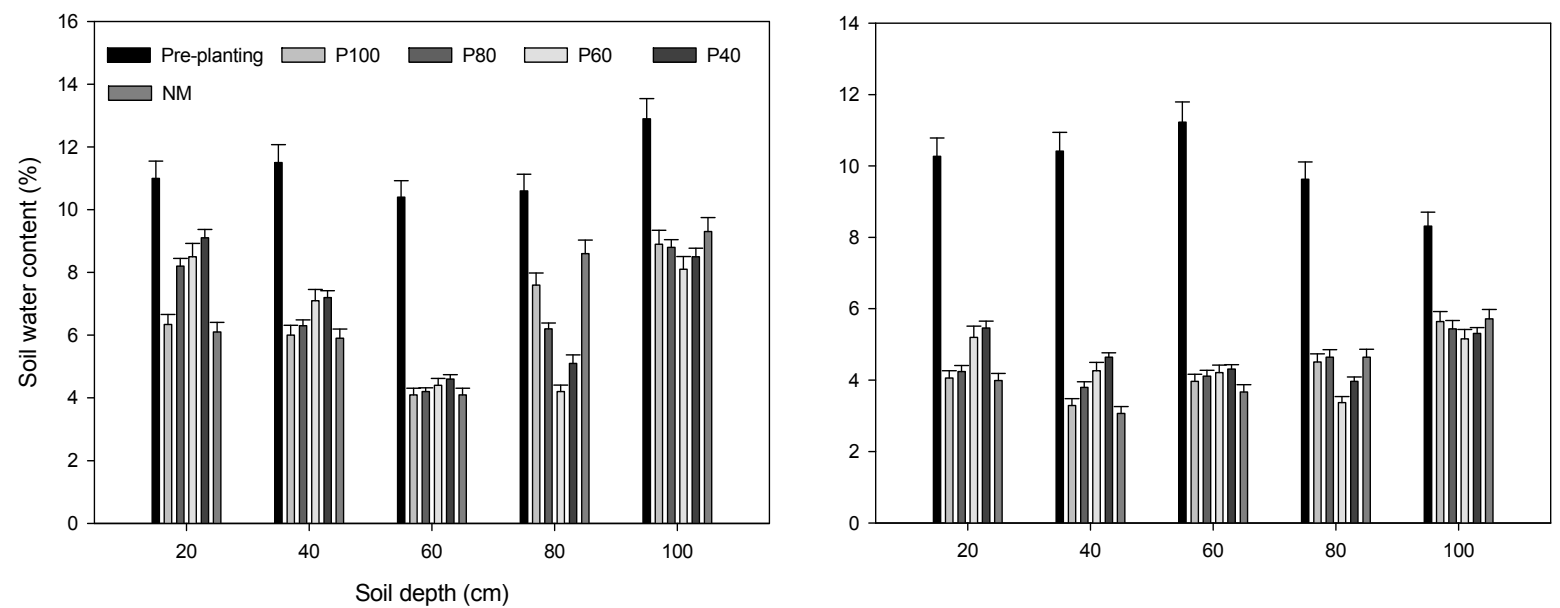

Figure 4. Soil water content $(0-100 \mathrm{~cm})$ at proso millet pre-planting and harvesting time under NM, P100, P80, P60 and P40 treatments in two proso millet growing seasons: 2010 (left panel), 2011( right panel)

\subsection{Proso Millet Yield and Water Use Efficiency}

The proso millet yield of four treatments in 2010 was significantly $(\mathrm{P}<0.05)$ higher than NM, yield of P60 was significantly $(\mathrm{P}<0.05)$ higher than others. In 2011 , tendency of proso millet yield was the same as the previous year (Table 2). The two years average yield among different treatments significantly increased by 73.87\%-147.00\% than NM. In 2010, ET was significantly lower compared with NM, decreased by 3.93 $\mathrm{mm}-101.4 \mathrm{~mm}$. In both years, WUE significantly increased by $75.58 \%-185.54 \%$ than NM, WUE of the P60 was higher than others.

Table 2. Proso millet yield, ET and WUE in all treatments in 2010-2011

\begin{tabular}{|c|c|c|c|c|c|c|}
\hline \multirow[b]{2}{*}{ Treatments } & \multicolumn{3}{|c|}{2010} & \multicolumn{3}{|c|}{2011} \\
\hline & $\begin{array}{c}\text { Yield } \\
\left(\mathrm{kg} \mathrm{ha}^{-1}\right)\end{array}$ & $\begin{array}{c}\text { ET } \\
(\mathrm{mm})\end{array}$ & $\begin{array}{c}\text { WUE } \\
\left(\mathrm{kg} \mathrm{ha}^{-1} \mathrm{~mm}^{-1}\right)\end{array}$ & $\begin{array}{c}\text { Yield } \\
\left(\mathrm{kg} \mathrm{ha}^{-1}\right)\end{array}$ & $\begin{array}{c}\mathrm{ET} \\
(\mathrm{mm})\end{array}$ & $\begin{array}{c}\text { WUE } \\
\left(\mathrm{kg} \mathrm{ha}^{-1} \mathrm{~mm}^{-1}\right)\end{array}$ \\
\hline P40 & $5789.19 b$ & 403.46 & $14.35 \mathrm{a}$ & $2220.95 b$ & 437.16 & $5.08 \mathrm{~b}$ \\
\hline P60 & $6294.05 \mathrm{a}$ & 436.70 & $14.42 \mathrm{a}$ & $2812.60 \mathrm{a}$ & 445.46 & $6.31 \mathrm{a}$ \\
\hline P80 & $5764.18 b$ & 455.77 & $12.65 \mathrm{~b}$ & $2220.95 b$ & 454.27 & $4.89 \mathrm{~b}$ \\
\hline P100 & $5188.02 \mathrm{c}$ & 469.90 & $11.04 \mathrm{~b}$ & $2101.12 \mathrm{c}$ & 463.75 & $4.53 b$ \\
\hline NM & $2548.16 \mathrm{~d}$ & 504.86 & $5.05 \mathrm{c}$ & $1208.46 \mathrm{~d}$ & 467.68 & $2.58 \mathrm{c}$ \\
\hline
\end{tabular}

In this experiment, it was assumed that treatment $\mathrm{NM}$ corresponded to a ridge width of $0 \mathrm{~cm}$ and all the data were analyzed regressively, indicating that the ridge width giving the highest yield was $64 \mathrm{~cm}$ in 2010 and $63 \mathrm{~cm}$ in 2011 (Figure 5). The ridge widths giving the highest WUE were $61 \mathrm{~cm}$ in 2010 and $60 \mathrm{~cm}$ in 2011 (Figure 6). These statistics implied that a ridge width between $60 \mathrm{~cm}$ and $64 \mathrm{~cm}$ was best for the proso millet yield and water use efficiency in this cultivation system. 


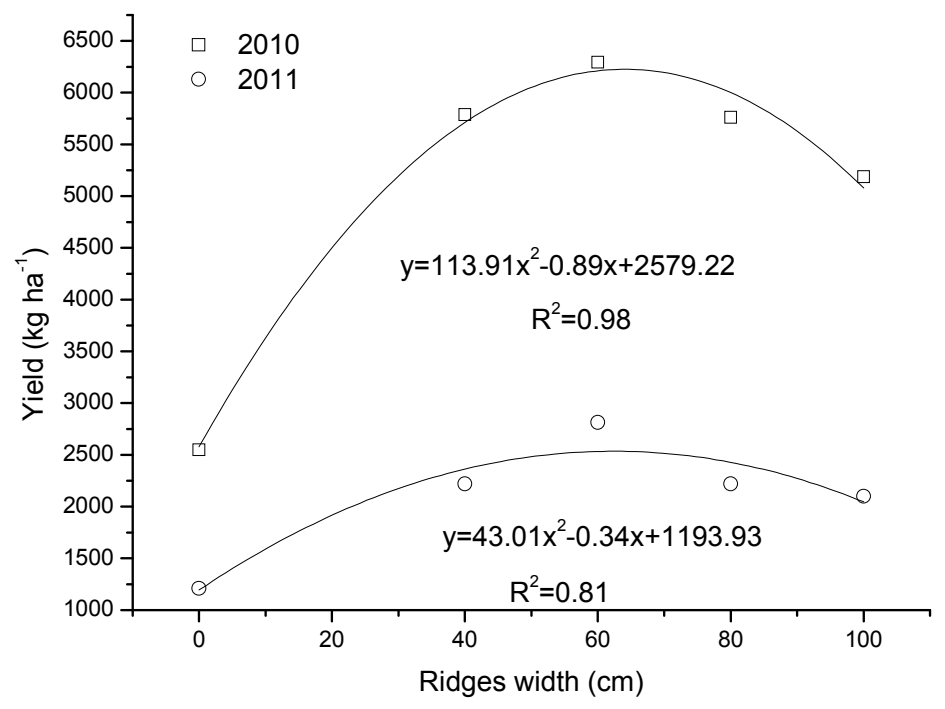

Figure 5. Yield of proso millet as a function of ridge width in P40, P60, P80, P100 and NM in 2010-2011

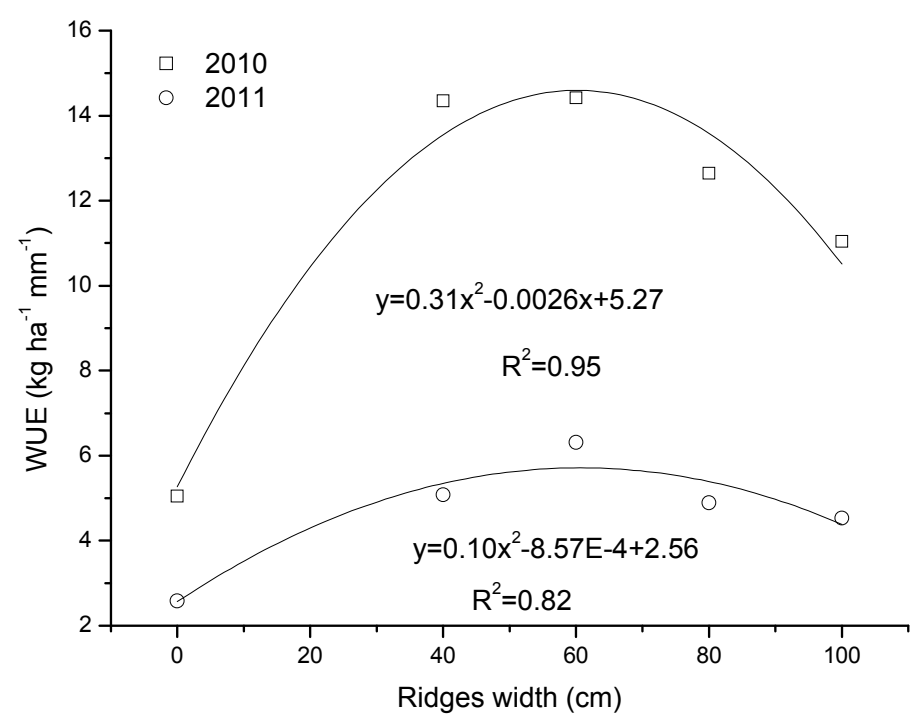

Figure 6. WUE of proso millet as a function of ridge width in P40, P60, P80, P100 and NM in 2010-2011

\section{Discussion}

Water harvesting based on alternating ridges and furrow with only the ridges mulched with white plastic film (PRFRH). Ridges mulched with plastic film collected rainfall to supply the water demand by the crop, it can improve plant growth and crop yield (Hou et al., 2010). This cultivation system was applied on potato (Wang et al., 2005; Yuan et al., 2003), maize (Zhang et al., 2011), wheat (Zhang et al., 2009), alfalfa (Yu et al., 2006; Li et al., 2007). However, for the moment, this cultivation system was not applied on proso millet in semiarid regions.

Proso millet roots can enter into $120 \mathrm{~cm}$ soil layers (Saseendran et al., 2009), and soil water storage and content had difference in different growth stages among treatments. SWS of treatments had difference during two seasons, SWS of all treatments decreased firstly, then increased in 2010; In 2011, SWS of all treatments decreased all the time, every treatment had also difference in different growth stages, however, SWS variation of treatments were not difference in the same stage (Figure 3). The reason might be that rainfall distributed unevenly 
in different growth stages (Figure 2), and root growth was influenced by different PRFRHs. Saving water of P40 was more better than others, that showed that the narrower of ridge and furrow width, the better effect of saving water, but its plant height and yield were lower than P60, the reason might be that P40 had advantage in topsoil $(0-60 \mathrm{~cm})$ water saving, disadvantage of improving roots growth, low side row yield, and little use in other depth $(60-100 \mathrm{~cm})$ between pre-planting and harvesting, but P60 might improve roots growth, increase roots to enter into soil depth, make use of limited rainfall effectively, enhance water use efficiency, obtain large side and middle row yield, and use soil water in all measured depth (Figure 4), also likely rainfall vertical infiltration under the P40 was weaker, and limited rainfall evaporation was easy relatively for large planting rowledge of the P40. Relevant results still needed to research further.

The observed variations in leaf area, dry matter, plant height during the two experimental seasons under the P60 were higher than others in the present research. In 2010, plant height, leaf area, dry matter and yield had more development compared with those of 2011, the reason might be that rainfall was significantly difference in both years (Figure 2), and ambient temperature was higher in 2011 than that of 2010 during two growing seasons, which likely led to more soil water evaporation. P60 treatment showed more advantage in yield, dry matter compared with other treatments in both years for large leaf area to enhance accumulation of photosynthesis matter.

It was well known that the yield was the product of water use efficiency multiplied by water use (Zhang et al., 2007). In order to improve crop yield, water use efficiency should be increased. The furrow and ridge system with film-mulched ridge should increase water use efficiency and yield because of water harvesting and control of evaporation from the topsoil (Deng et al., 2006; Zhou et al., 2009). Hou et al (2010) reported that water use efficiency of the potato increased by $197 \%-258 \%$, and yield increased by $176 \%-237 \%$ compared with NM under the PRFRH system. Zhang et al (2011) reported that water use efficiency of spring-sown maize increased by $17 \%$, and yield increased by $19 \%$ compared with NM under the PRFRH system. In present research, proso millet used was a drought-resistance crop, which had been planted for many years in this region. The proso millet in all treatments were allowed to fully mature, yield of proso millet increased by $73.87 \%-147.00 \%$, and water use efficiency increased by $75.58 \%-185.54 \%$ compared with NM under the PRFRH system, the results showed that the PRFRH system was suited for proso millet planting. However, water use efficiency of treatments was low except P60, these showed that there was a optimal ridge and furrow width on the proso millet under the PRFRH system. Therefore, in order to obtain the optimal ridge and furrow width, regression method was used. The ridge widths giving the highest yield and water use efficiency were $63 \mathrm{~cm}, 64 \mathrm{~cm}$ in 2010 , and $61 \mathrm{~cm}, 60 \mathrm{~cm}$ in 2011 , respectively, and furrow width was the same as ridge width.

\section{Conclusion}

This cultivation system significantly increased soil water content of the furrow, and promoted proso millet growth and yield development. Water harvesting from plastic film on ridges supplied water to proso millet of the furrow, and the plastic film on ridges inhibited soil water evaporation, which improved water use efficiency and increased proso millet yield. Although, rainfall amount and distribution had large difference in two years, the optimal ridge and furrow mode was similar for two years: a ridge : furrow width was $60 \mathrm{~cm}-64 \mathrm{~cm}$.

\section{Acknowledgements}

This study was supported by Special Fund for Agro-scientific Research in the Public Interest (200903007) and China Agriculture Research System (CARS-07-12.5-A9).

\section{References}

Ali, M., \& Mohammad, S. (2009). Effect of Every-Other Furrow Irrigation on Water Use Efficiency, Starch and Protein Contents of Potato. Journal of Agricultural Science, 1(2), 107-112.

Deng, X. P., Shan, L., Zhang, H. P., \& Neil, C. T. (2006). Improving agricultural water use efficiency in arid and semiarid areas of China. Agricultural Water Management, $80, \quad 23-40$. http://dx.doi.org/10.1016/j.agwat.2005.07.021

Fisher, P. D. (1995). An alternative plastic mulching system for improved water management in dryland maize production. Agricultural Water Management, 27, 155-166.

Gupta, G. N. (1995). Rainwater management for tree planting in the India desert. J. Arid Environ, 31, 219-235.

He, X. F., Cao, H. H., \& Li, F. M. (2007). Econometric analysis of the determinants of adoption of rainwater harvesting and supplementary irrigation technology (RHSIT) in the semiarid Loess Plateau of China. Agricultural Water Management, 89, 243-250. http://dx.doi.org/10.1016/j.agwat.2007.01.006 
Hou, X.Y., Wang, F. X., Han, J. J., Kang, S. Z., \& Feng, S. Y. (2010). Duration of plastic mulch for potato growth under drip irrigation in an arid region of Northwest China. Agricultural and Forest Meteorology, 150, 115-121. http://dx.doi.org/10.1016/j.agrformet.2009.09.007

Jia, Y, Li, F. M., Wang, X. L., \& Yang, S. M. (2006). Soil water and alfalfa yields as affected by alternating ridges and furrows in rainfall harvest in a semiarid environment. Field Crops Research, 97, 167-175. http://dx.doi.org/10.1016/j.fcr.2005.09.009

Lal, H., Silva, A. S., Porto, E. R., \& Costa, A. E. M. (1984). Animal-drawn ridger-blade and its use in a new type of in situ rainwater harvesting. Pesqui Agropecu Bras, 19, 1385-1393.

Lampurlanes, J., Angas, P., \& Cantero-Martinez, C. (2002). Tillage effects on water storage during fallow, and on barley root growth and yield in two contrasting soils of the semi-arid Segarra region in Spain. Soil \& Tillage Research, 65, 207-220.

Li, X. L., Su, D. R., \& Yuan. Q. H. (2007). Ridge-furrow planting of alfalfa (Medicago sativa L.) for improved rainwater harvest in rainfed semiarid areas in Northwest China. Soil \& Tillage Research, 93, 117-125. http://dx.doi.org/10.1016/j.still.2006.03.022

Li, X. Y., Gong, J. D., Gao, Q. Z., \& Li, F. R. (2001). Incorporation of ridge and furrow method of rainfall harvesting with mulching for crop production under semiarid conditions. Agricultural Water Management, 50(3), 173-183.

Pan, Q. Y., Pan, X. L., Yang, F. Y., Wen, X. F., Pei, F., Pan, S. R., Pan, T. Y., \& Shi, Y. H. (2012). Water Use Efficiency and Eco-Niche-Yield Prediction of Rainfed Wheat in China's Loess Plateau. Journal of Agricultural Science, 4(1), 143-153. http://dx.doi.org/10.5539/jas.v4n1p143

Saseendran, S. A., Nielsen, D. C., Lyon, D. J., Ma, L., Felter, D. G., Baltensperger, D. D., ... Ahuja, L. R. (2009). Modeling responses of dryland spring triticale, proso millet and foxtail millet to initial soil water in the high plains, 113, 48-63. http://dx.doi.org/10.1016/j.fcr.2009.04.008

Tian, Y, Derong, Sua, Li, F. M., \& Li, X. L. (2003). Effect of rainwater harvesting with ridge and furrow on yield of potato in semiarid areas. Field Crops Research, 84, 385-391. http://dx.doi.org/10.1016/s0378-4290(03)00118-7

Tolk, J. A., Howell, T. A., \& Evett, S. R. (1999). Effect of mulch, irrigation, and soil type on water use and yield of maize. Soil \& Tillage Research, 50, 137-147.

Wang, X. L., Li, F. M., Jia, Y., \& Shi, W. Q. (2005). Increasing potato yields with additional water and increased $\begin{array}{lllll}\text { soil temperature. Agricultural Water } & \text { Management, } & \text { 78, } & \text { 181-194. }\end{array}$ http://dx.doi.org/10.1016/j.agwat.2005.02.006

Wang, Y. J., Xie, Z. K., Malhi, S. S., Vera, C. L., Zhang, Y. B., \& Wang, J. N. (2009). Effects of rainfall harvesting and mulching technologies on water use efficiency and crop yield in the semi-arid Loess Plateau, China. Agricultural Water Management, 96, 374-382. http://dx.doi.org/10.1016/j.agwat.2008.09.012

Xie, R., Li, S., Jin, Y., Li, X., Tang, Q., Wang, K., \& Gao, S. (2008). The trends of crop yield responses to conservation tillage in China. Journal integrative of agricultural research, 41(2), 397-404.

Zhang, J. Y., Sun, J. S., Duan, A. W., Wang, J. L., Shen, X. J., \& Liu, X. F. (2007). Effects of different planting patterns on water use and yield performance of winter wheat in the Huang-Huai-Hai plain of China. Agricultural Water Management, 92, 41-47. http://dx.doi.org/10.1016/j.agwat.2007.04.007

Zhang, S. L., Lars, L., Harald, G., Yanan, T., Xueyun, Y., \& Quanjiu, W. (2009). Effects of mulching and catch cropping on soil temperature, soil moisture and wheat yield on the Loess Plateau of China. Soil \& Tillage Research, 102, 78-86. http://dx.doi.org/10.1016/j.still.2008.07.019

Zhang, S. L., Li, P. R.,Yang, X. F., Wang, Z. H., \& Chen, X. P. (2011). Effects of tillage and plastic mulch on soil water, growth and yield of spring-sown maize. Soil \& Tillage Research, 112, 92-97. http://dx.doi.org/10.1016/j.still.2010.11.006

Zhou, L. M., Li, F. M., Jin, S. L., \& Song, Y. J. (2009). How two ridges and the furrow mulched with plastic film affect soil water, soil temperature and yield of maize on the semiarid Loess Plateau of China. Field Crops Research, 113, 41-47. http://dx.doi.org/10.1016/j.fcr.2009.04.005 